\title{
Optimization of the Students Management Mode in Colleges and Universities
}

\author{
Gaoshen Li \\ Academic Research Office \\ Huanghe Science and Technology College \\ Zhengzhou, China
}

\begin{abstract}
It is in colleges and universities that the exports of scientific research and other specific talents being cultivated. And they are responsible for inheriting the civilization, cultivating talents and serving the society. It is an important task for them to take measures to deepen the reform of student management, raise the quality of talents to coordinate with the market -oriented and diversified society.
\end{abstract}

\section{Keywords-cultivate talents; education; management mode}

\section{INTRODUCTION}

Management innovation is an important feature for the society and an inevitable requirement of its progress. Modernization of education requires the modernization of student management mode, and the innovation of education needs the innovation of management mode. For the management of university students, the innovation of mode is a vital guarantee to realize the university education progress. As a subsystem of the social system, higher education should be guided by the Scientific Outlook on Development, and establish a "people-oriented" teaching and student management mode to promote the comprehensive and harmonious development of undergraduates. In the student management work, we should carry out people-oriented and innovative management to realize harmonious and all-round development of students.

\section{THE CONNOTATION AND SIGNIFICANCE OF THE STUDENT-ORIENTED MANAGEMENT MODE}

It reflects the humanism in education to put forward people-oriented student management theory. There has been long term exploration by educationists for the implementation of people-oriented management mode in colleges and universities. Thus, there are different ways of understanding. Some from the perspective of interpersonal relationships think that people-oriented management should be based on the respect of student's personality, and create mutual understanding and cooperating environment, thus to reach the goal of education through the deep relation among instructors, teachers and students. And some start from the need and development of individuals. They insist that people-oriented management is the one that directed by the theory of care, respect, encouragement and development. It should make students the subject of educational activities, fully develop the potential of students and raise their ability, thus to achieve the goal of education. Others start from the behavior and mental development of students. They hold the view that the peopleoriented management is to focus on the importance of behavior and psychological condition in management by taking emotion communication management, activity execution management and student independent management. The above 3 methods are following the connotation of people-oriented management, but with deficiencies. They all make the students as audience, carry out management subjectively in a superior manner. Focus too much on personal values self-realization, while ignoring the close relationship between personal development and social environment, which means that they do not know the objectives and significance of student management. For example, the first one focuses on the emotion and its original environment but those of educationists. The second strengthens the subjective promotion of students but still from the teachers' point. What's worse, the third one just considers it as management instead of thinking about the development value of students.

The development of students should be the base of peopleoriented management. We should create environment and condition for them. It should also focus on the developing of their characteristics and all-round sustainable development. Anyway, all student management work is start from students and around them. So here should be perfect explanation of people-orientation and student-orientation. Every student is with him or her own independent thinking, unique personality, and emotion. Therefore, people-orientation should be the starting point of the reform of the management mode.

The core of people-orientation lies in the affirmation of humanity, the trust in their potential, the pursuit of freedom and democracy. Academic freedom and freedom of thought are the lifeblood of university. People-oriented education is, to make students as the foundation of management. Emphasize on humanity, meet their reasonable needs maximally, and fully respect human values and dignity. People-oriented student management requires the way to carry out working by taking students as the center to create a good learning environment both materially and spiritually for students. Management concept should be concentrated on humanistic care. The work should aim at mobilization of the positive factors of students, stimulation of students' creativity, and the exploration of their subjective initiative maximally. 
Adhere to the people-oriented theory and take the cultivation of student's ability as the starting point and aim. Meanwhile, teaching activities should be linked with student's happiness, freedom, dignity, creativity and value. Management is no longer simply by the command and regulations, but in a way that includes the combination of the scientific democracy and equality and freedom, humanistic spirit and modern science and technology to cultivate "all-round development" personnel with distinguished characteristic.

\section{THE IMPLEMENTATION OF INNOVATION ON PEOPLE- ORIENTED STUDENT MANAGEMENT MODE}

As a concept, "People-oriented" is reflected in all student management works. In general, innovation should be stared from the following aspects: First of all, updating the management theory. It is the basic need for people-oriented management to meet the needs of students' development and serve for them. What's more, all-round development of students is the fundamental goal of student management. People-oriented management should be the kind of management that update theory frequently, truly make students as the focus of management, meet students' need and create social and school environment for reaching their goal, achieving their physical and mental development and value creation.

Students should be treated equally. Managers should treat students equally, objectively and fairly with appreciation, enthusiasm, and love. They should also meet students' reasonable needs as much as possible. And if there are problem with students, they should give them instruction at once. Strengthen on the management service system by providing students with more information for reference. Such as curriculum information, teachers' information, work-study information, academic exchange information. At the same time, there is more spare time for college students to choose to do things they are interested in, so they have higher requirement on the rational distribution of teaching resources. Therefore, related services about the use of classroom, reading services, audio-visual studio, Internet services, sports facilities, practical aspects must be strengthened. All works should be started from the needs of students, concern about the personality development and reflect humanistic care.

Secondly, we must strengthen on the system construction by establishing a scientific management evaluation mechanism, which is an important guarantee for people-oriented management. People-oriented management philosophy reflects the autonomy, democracy, flexibility and development characteristics of management. All activities are carried out by people, who can be students or managers. Thus, respect and communication should be the priority of management. Everything needs to be carried out according to the needs of people and the law of their development. Therefore, there should be the management theory of autonomy, democracy, flexibility and development. Autonomy is to put students at the dominant position, trust students' management ability, and make them play main roles; believe that students can do selfrestraint, and let themselves managing in available range, instead of controlling them or being opposite with them. Democracy is to ask for ideas and advice from students and let them join in the management work. Flexibility means to seek for methods and ways to meet with the real conditions of students. Development characteristic is to reform and innovate management ideas with time going on; and continuously explore management mode and measure to make better development of students and universities and colleges. "People-oriented" educational thinking requires the integration of training standard with diversified and distinctive training process, which is called the combination of "hardness and softness."

In the teaching management, a new system based on "credit system" should be built. It should be humanistic by focusing on students and educational services, enhancing the flexibility of teaching system, and giving students more space to choose things they want to learn. In this way, students can learn things independently. Meanwhile, it is also in line with the principle that teaches students in accordance with their aptitude, which can help the cultivation of talents with distinctive characteristics and creative ideas. The restriction of major changing should be released, allowing students to choose their own majors freely. The system of student status management should also be reformed and adjusted accordingly. Its principle is to reflect the student-oriented theory and to serve for the students' study to a maximum extent. Management in this way can help cultivate talents that are needed in the era of knowledge economy. It is one of the creative management modes and in line with the trend of advanced student management method as well.

Finally, we must actively explore the management methods to achieve a pragmatic innovation of the new pattern of people-oriented management. "People-oriented" student management varies a lot according different places, target students and time, instead of being stereotyped, procedural and formulaic. It is a kind of management that requires the combination of rigid management and flexible management, explicit management and implicit management, teacher motivation and self-management to achieve students' comprehensive development. In the unity of rigid and flexible management, we should not only help the reflection of the realistic value of teachers as managers, but also fully respect the emotional needs, personality independence and individual freedom of students. Teachers shouldn't do the maintenance of the system, while they should help to create a learning and developing environment and good harmonious and upward atmosphere by coordinating the relationship between schools and students.

In the unification of explicit and implicit management, because of the great differences in personality among university and college students, this requires managers to adopt different communication methods and educational methods for students with different personalities and to make corresponding adjustment in different ways, soft environment, and management measures. Not only their way of thinking, dynamic psychological change, but also personality characteristics, cultural qualities and moral standards should be taken into consideration. It is necessary to take obvious and effective management measures, and also to influence them by providing corresponding conditions. Strengthen on selfmanagement and education, while teachers motivate them by 
the encouragement, sharpening and interest-driven process. Provide students with spiritual impetus and action guide to stimulate students to create internal motivation, so that students will regulate their own behavior automatically and in this way they can understand their own social function and value.

\section{CONCLUSION}

To conclude, people-oriented student management is to pursue novelty in the way of concerning about the daily life of students and learning behavior. In management, we should put students on the prior position and do it in a creative manner. In this way, the comprehensive, harmonious and sustainable development can be realized by adhering to the management concept of "people-oriented and harmonious development", adapting to the requirements of the Scientific Outlook on Development in the new era, promoting the positive learning outlook and outlook on life and values, realizing the reform and innovation of student management mode.

\section{REFERENCES}

[1] Nie Xin. Study of Ideological and Political Education in the New Era [J]. Science and Technology Review, 2014 (z3): 340,341.

[2] Ding Baocai. Investigation on Training Mode of College Student Cadres under the Background of Micro Age [J]. Technology Wind, 2013 (21): 198.

[3] Chen Xiaoxiang. Exploration on "Four in One" Student Management Mode in Colleges and universities [J]. China Management Magazine, 2014 (4) : 474

[4] Zhang Shunyou, Tan Yaya, Shen Yuhuan, etc. Exploration on Student Management Mode Based Mainly on Dormitory [J]. Industry \& Science Tribune, 2014 (3): 242-243.

[5] Wang Yan, Li Wei. Exploration on University Student Management Mode under the View of Education Democracy [J]. Journal of Shandong Education Institute, 2009, 24 (5): 15-17.

[6] Wang Na. American University Student Organization Management Mode and Inspiration [J]. Academic Research, 2014 (4): 149-152. 